\title{
Much ado about social outcomes?
}

\author{
Citation for published version (APA):
}

Fregin, M-C., Bijlsma, I., \& van der Velden, R. (2018). Much ado about social outcomes? Effective skill, skill mismatch, and their relation with job satisfaction and other social outcomes. Maastricht University, Graduate School of Business and Economics. GSBE Research Memoranda No. 017 https://doi.org/10.26481/umagsb.2018017

Document status and date:

Published: 17/05/2018

DOI:

10.26481/umagsb.2018017

Document Version:

Publisher's PDF, also known as Version of record

\section{Please check the document version of this publication:}

- A submitted manuscript is the version of the article upon submission and before peer-review. There can be important differences between the submitted version and the official published version of record.

People interested in the research are advised to contact the author for the final version of the publication, or visit the DOI to the publisher's website.

- The final author version and the galley proof are versions of the publication after peer review.

- The final published version features the final layout of the paper including the volume, issue and page numbers.

Link to publication

\footnotetext{
General rights rights.

- You may freely distribute the URL identifying the publication in the public portal. please follow below link for the End User Agreement:

www.umlib.nl/taverne-license

Take down policy

If you believe that this document breaches copyright please contact us at:

repository@maastrichtuniversity.nl

providing details and we will investigate your claim.
}

Copyright and moral rights for the publications made accessible in the public portal are retained by the authors and/or other copyright owners and it is a condition of accessing publications that users recognise and abide by the legal requirements associated with these

- Users may download and print one copy of any publication from the public portal for the purpose of private study or research.

- You may not further distribute the material or use it for any profit-making activity or commercial gain

If the publication is distributed under the terms of Article $25 \mathrm{fa}$ of the Dutch Copyright Act, indicated by the "Taverne" license above, 
Marie-Christine Fregin, Ineke Bijlsma,

Rolf van der Velden

Much Ado About Social

Outcomes?

Effective skill, skill mismatch, and their own relation with job satisfaction and other social outcomes

$\mathrm{RM} / 18 / 017$

\section{GSBE}

Maastricht University School of Business and Economics

Graduate School of Business and Economics

\section{P.O Box 616}

NL- 6200 MD Maastricht

The Netherlands 


\title{
Much Ado About Social Outcomes?
}

\section{Effective skill, skill mismatch, and their relation with job satisfaction and other social outcomes}

\author{
Marie-Christine Fregin \\ Ineke Bijlsma \\ Rolf van der Velden \\ Research Centre for Education and the Labour Market (ROA), \\ School of Business and Economics, Maastricht University, Netherlands \\ Correspondence and author details: \\ Marie-Christine Fregin (Corresponding Author), Email: m.fregin@maastrichtuniversity.nl \\ Ineke Bijlsma, Email: i.bijlsma@maastrichtuniversity.nl \\ Rolf van der Velden, Email: r.vandervelden@maastrichtuniversity.nl
}

\section{Abstract}

Skills and skill mismatches are claimed to have major consequences for societies and individuals, although convincing evidence mainly exists for wages. Our article examines the association between skill mismatch and job satisfaction as well as other social outcomes, such as political efficacy and social trust. Drawing on data from the OECD Programme for the International Assessment of Adult Competencies (PIAAC), we contribute to sociological research by applying the 'effective skill' concept, a new conceptual approach to measure skill mismatch. We relate this new concept to job satisfaction and other social outcomes, comparing our results with alternative skill mismatch indicators. Our findings provide empirical evidence for two important messages: First, we provide evidence that once we use objective indicators for the skill match - and we make use of all measures that we currently have - there is no association between skill mismatch and job satisfaction. In fact, job satisfaction is driven by skill use, not by skill mismatches or skill proficiency. Second, we show that effective skill and skill mismatch are associated with other social outcomes, having quite considerable effects especially on political efficacy.

Keywords: Skill Mismatch, Effective skill, Overskilling, Job Satisfaction, Social Outcomes

Acknowledgements: We would like to thank Jim Allen (ROA, Maastricht University), Jan Heisig (WZB, Berlin), Davey Poulissen and Maria Ferreira (ROA), and the participants of the 4th International PIAAC conference (November 2017, Singapore) for valuable comments and suggestions. 


\section{Introduction}

Job-worker mismatches are claimed to be a pervasive and persistent phenomenon (Green, 2013; Cedefop, 2018). The significance of the literature on skill mismatch and overqualification is driven by the fact that the mass participation in higher education has changed the workforce of industrialised societies. The most important mechanism of adjustment of labour markets to the oversupply of highly educated workers is overqualification (Büchel, de Grip, and Mertens, 2003: 9). Given that, it does not come as a surprise that the proportion of mismatched workers has increased over time (Verhaest and Van der Velden, 2013). Evidence suggests that the consequences may be increasing as well (Green and Zhu, 2010), particularly if employees get trapped in a job for which they are overeducated (Voßemer and Schuck, 2016). Although skill mismatch, and especially overskilling, is claimed to have major consequences for societies and individuals, convincing evidence mainly exists for wages (see e.g. Allen and Van der Velden, 2001; Hanushek and Woessmann, 2015; Heyes, Tomlinson, and Whitworth, 2017). However, if employees are in a situation in which their jobs require more (or fewer) skills than they can provide, it is not all about money. There are strong indications that skill mismatches, and particularly overskilling, might have a negative effect on job satisfaction as well (e.g. Allen and van der Velden, 2001; Allen, Levels, and van der Velden, 2013; Verhaest and Verhofstadt, 2016). Nevertheless, the empirical evidence for this is based on subjective indicators of the skill match and this has not been backed up yet by research based on objective indicators of skill mismatch. When it comes to other social outcomes of skill mismatch, a deeper examination is largely missing in the discourse (Green and Henseke, 2016).

The political and academic interest in skills and mismatches merely rests upon the concern that skills are not only important for the individual well-being, but vital for the proper functioning of labour markets, democracies, and societies as a whole (European Commission, 2016). Skills and mismatches are thereby considered to have a broad impact, also affecting aspects of private and social life outside work (OECD, 2017; Desjardins and Schuller, 2006). To capture the full impact of skills and skill mismatches, we must consider potential social outcomes in addition to economic consequences (see Freeman, 1976; McMahon, 2009; Green and Henseke, 2016). Job satisfaction, as a subjective and work related indicator, is one of such outcomes. But other indicators like social trust or political efficacy are relevant as well. Job satisfaction is one of the key determinants of general well-being, and thus bridges the worlds of work and society. Trust and efficacy have externalities that spill over to benefit other people, contributing to social cohesion and hence social capital (McMahon, 2009: 223; Schleicher and Thorn, 2016; European Commission, 2016). A key dimension of the social capital of a society is social trust, concerning 
interpersonal trust and generalised trust in others. Political trust and the perception of the individual political efficacy form a vital part of political capital, a key pillar of each democracy (Schleicher, Thorn, 2016: 8). Social trust and the perception of the own (political) efficacy are related to skills and education as both require individuals to have the cognitive and analytical competency that is needed to "develop, maintain, and (perhaps) restore" trust, allowing people e.g. to appreciate co-operation with others in all kinds of settings (see Borgonovi and Burns, 2015: 10).

Although skills are thus related to both economic and social outcomes, skill mismatch (i.e. skills shortage or surplus) must also have an effect. This is the reason why not only the interest in skills but also concerns about skill mismatches are growing both in politics and academia (European Commission, 2016). In his seminal article on overeducation, Peter Sloane raised the question about social outcomes, asking: Is overeducation "Much Ado About Nothing?" (Sloane, 2003). At the time, however, good mismatch indicators were lacking, and the empirical evidence was mainly based on workers' self-assessment of the skill match. To date, the OECD Programme for the International Assessment of Adult Competencies (PIAAC) provides detailed information on the actual skills of workers, giving new and better opportunities for the investigation of returns to skills and the development of mismatch indicators that are based on objective rather than subjective data. Nevertheless, skill mismatch still poses challenges to sociological research and related academic disciplines, as no consensus exists on how to capture the phenomenon and what constitutes an adequate indicator.

The objective of our paper is twofold: First, building on the discussion that skills have a broader impact, we dig deeper into the relation between skills, skill mismatches and social outcomes. Making use of the unprecedented possibilities provided by PIAAC data in an explorative way, we shed new light on how skill mismatches might affect job satisfaction, and furthermore examine other social outcomes, such as political efficacy and social trust. Second, we contribute to sociological research by applying a new approach to measure skill mismatch: the 'effective skill' concept, developed by Van der Velden and Bijlsma (2018). This concept is based on a theoretical re-thinking of the relation between skill proficiency and skill use. The authors integrate both into a new concept: 'effective skill', defined as the multiplicative function of skill proficiency and skill use. The intuitive understanding is that skills can have no effect if they are not put to productive use - and, vice versa, using skills can only have a small effect if proficiency is low. So far, the concept has only been tested on wages, where it performed superior to alternative approaches (Van der Velden and Bijlsma, 2018). In our article, we relate the effective skill concept to job satisfaction and other social outcomes, comparing our empirical findings with alternative indicators, developed by Allen, Levels, and Van der Velden (2013) and Pellizzari and Fichen 
(2013). Using PIAAC data, our article relies on objective skills measurements for male fulltime employees in 22 industrialised countries.

Adapting the new effective skill concept to address social outcomes, we present an illuminating new way of thinking about the phenomenon of skill mismatches. We provide evidence for two important messages: First, we show that there is no relation between skill mismatch and job satisfaction once we use objective measures for the skill match. We show that the relation between skill mismatch and job satisfaction is entirely driven by skill use: People who use their skills more, are more likely to be satisfied with their job. Once we control for this, there is no additional effect of skill mismatch. Second, we show that not only skills, but also skill mismatches are related to other social outcomes, such as political efficacy and social trust.

The article begins with a brief review of the state of the art concerning skill mismatch and related consequences. After that, we describe our dataset and analytical methods. We then investigate social outcomes of effective skill and over- and underperformance in effective skill before we conclude with a discussion of our results.

\section{Skill mismatch and social outcomes}

Skill mismatch, in its vertical dimension, refers to a working situation in which the skills possessed by a worker do not meet or exceed the skill requirements of his or her workplace. For example, we define a worker as overskilled if he or she has more skills than required by the workplace, hence the worker does not have the chance to fully exploit his or her talents. Underskilled workers, by contrast, have fewer skills than required by their jobs. Against the background of rising demands for specific skills in the knowledge economy, skills are "widely regarded as a core object for policy interventions and analytical research" (Green, Felstead, Gallie, and Inanc, 2013: 9). There is a common belief that by promoting skills and improving the respective policies, governments and other collective agents can enhance both economic prosperity and social cohesion (see Green et al., 2013: 4; McMahon, 2009; European Commission, 2016).

There has been a large amount of research on skill mismatches and their impact during the past decades. Usually, the literature focuses on wages. Several studies show that wage returns to excess skills are less than returns to required skills (e.g. Hartog, 2000; Perry et al., 2014; Hanushek et al., 2015; Van der Velden and Bijlsma, 2018). Previous studies also addressed job satisfaction and mental well-being, finding that both are lower for overeducated employees (e.g. Allen and Van der Velden, 2001; Green and Zhu, 2010; Allen, Levels, and Van der Velden, 2013; Verhaest and 
Verhofstadt, 2016; Green and Henseke, 2016; Heyes, Tomlinson, and Witworth, 2017). Given the lack of data on skills before the PIAAC survey was conducted, earlier studies are merely based on measures that capture the self-reported perception of the skill match. Still, we would also expect that skill mismatches based on objective indicators would have an impact on job satisfaction. We expect that job satisfaction is positively related to requirements in the job as challenging jobs may increase job satisfaction (Van der Velden and Verhaest, 2017). And that any surplus of skills will negatively impact job satisfaction. The reason is that workers will compare themselves either with workers in the same job that deploy a lower level of effective skill or compare themselves with workers in jobs that require the same higher level of effective skill. In both cases, they will find themselves in a situation that is disadvantageous, leading to lower levels of job satisfaction. ${ }^{1}$ The relation of the reverse situation of underperformance to job satisfaction is less clear. On one hand, a small skill shortage may be positive for the worker as it makes the job more challenging. On the other hand, if the shortage is too big, it may lead to stress and therefore less job satisfaction (Van der Velden and Verhaest, 2017). We therefore refrain from formulating a specific hypothesis on the effect of underperformance.

The perception of individuals of exerting influence on political issues as well as having trust in other people, is deeply rooted in individual experiences and based on cognitive and analytical capacities that are needed to develop and maintain both trust and an adequate perception of the own efficacy (see Borgonovi and Burns, 2015). A high skill proficiency level combined with the experience of task-related efficacy at work due to a productive use of one's skills, may serve as an empowering combination, increasing both engagement and effort in other domains of life (Bandura, 1977). People who feel that they are in control of their work, may also feel more efficacious when it comes to political processes. We would also expect a positive relation with social trust, which is known to be related to skill proficiency and education, but which may also be underpinned by the experience caused by an efficacious exploitation of one's own skills and talents. We would expect that skill mismatches are also related to these social outcomes, in the same way as they would affect wages.

Evidence suggests that the association between mismatches and wages are best explained by matching models, assuming that the combination of supply and demand determines outcomes (Duncan and Hoffman, 1981). In the so-called Overeducation-Required educationUndereducation model (ORU model), Duncan and Hoffman (1981) break down the individual

\footnotetext{
${ }^{1}$ Note that this is different than in the case of wages where overskilled workers still have a positive payoff.
} 
educational attainment into three components (years of required education for the job, years of overeducation, and years of undereducation), providing evidence of economic effects of educational mismatches. While required education yields the largest wage premium, economic returns to years of overeducation are smaller, though positive and significant. By contrast, years of undereducation result in wage penalties. These results have been replicated in many studies all over the world (Hartog, 2000; Groot and Maassen van den Brink, 2000). Years of education required on the job thereby serve as crucial control proxying job requirements.

Van der Velden and Bijlsma (2018) use the ORU logic to develop the effective skill concept, identifying three underlying components of effective skill: the typically required effective skill in an occupation, and the individual overperformance or underperformance. "Overperformance" refers to a situation in which the effective skill deployed by a worker is considerably higher than the effective skill required by the job, whereas "underperformance" is defined as the opposite. Using the new concept to develop an 'effective skill matching model', Van der Velden and Bijlsma examine the effects of required effective skill and effective skill mismatches on wages, showing a strong association between effective skill and wages. Furthermore, the authors show that the concept of effective skill is theoretically and empirically sound and the associated skill mismatch model superior to alternative models (Van der Velden and Bijlsma, 2018: 23). In the article at hand, we extend the analyses by Van der Velden and Bijlsma (2018) to include job satisfaction and other social outcomes. We apply the same logic of the classical Duncan and Hoffman (1981) ORU model. If returns to skills are flexible, and if social outcomes such as job satisfaction, political efficacy, and social trust are related to both job requirements in terms of effective skill as well any mismatch between those requirements and the effective skill a worker actually deploys, we would expect to find support for the following hypotheses:

H 1. Required effective skills are positively related to job satisfaction, political efficacy and social trust.

H 2. Overperformance is negatively related to job satisfaction.

H 3. Overperformance is positively related to political efficacy and social trust as additional effective skills pay off, whereas the relation between underperformance and these outcomes is negative.

\section{Data and methods}

To empirically test the theoretical notions outlined above, we use the PIAAC data (see OECD, 2013 , 2016). In this survey, adults aged 16-65 have been tested in key skills related to information 
processing at work and in daily life (literacy, numeracy, and problem-solving in technology-rich environments). We use data for the 22 countries that participated in PIAAC Round I (2011-12), excluding Russia and Australia due to issues regarding data reliability and data protection legislation. From the Canadian sample, we take a random sample of about 20 percent to avoid overrepresentation in the dataset. We restrict our analyses to male employees because labour market engagement, especially of older generations, is different for women. Moreover, the mechanisms that drive job satisfaction and the other outcomes under study may also be different for men and women. We exclude part-time workers because the indicators in PIAAC assessing the frequency of skill use are more adequately designed for fulltime workers. We also exclude self-employed, members of the armed forces, unpaid family workers and students/interns. Our analyses rely on representative samples of male fulltime working employees in 22 industrial countries based on micro data for 30,387 respondents. We focus on the skill domain of numeracy. As a robustness check, we also compute our basic models using literacy to analyse whether our results are consistent over different skill domains.

As the PIAAC survey covers all jobs in a large number of countries, a direct objective measure of skill matching based on a systematic evaluation of job requirements does not exist. Various approaches have been developed to proxy skill requirements (for details see Hartog, 2000; Van der Velden and Bijlsma, 2018). To operationalise skill mismatch, we make use of the new 'effective skill' concept developed by Van der Velden and Bijlsma (2018). The authors define effective skill as the multiplicative function of skill proficiency and skill use. Firmly based on efficacy theory (Bandura, 1977) and use-it-or-lose-it theories (Salthouse, 2006), the concept provides an explicit mechanism for relating skills to productivity and performance.

Van der Velden and Bijlsma (2018) have developed a matching model for effective skill, following the logic of the ORU model and a so-called realised matches (RM) approach (Hartog, 2000). The RM approach assumes that every occupation has a unique required level of effective skill, defined as the average effective skill level in that occupation ${ }^{2}$. If the effective skill of a certain worker lies more than 0.5 standard deviation above the required level in that occupation, the person is classified as overperforming. If a worker's effective skill lies more than 0.5 standard deviation below the required level, this person is classified as working below the required effective skill level (underperforming).

\footnotetext{
2 To estimate the robust average skill proficiency levels for country-specific ISCO 2-digit occupation categories, we resort to the calculations performed by Allen and Bijlsma (2015). In their paper, Van der Velden and Bijlsma (2018) show that the total explained variance does not change if they use 3-digit instead of 2-digit ISCO categories.
} 
In PIAAC, skill use is assessed on the basis of an indicator that rates the frequency of skill use at the workplace with a six-item battery (each of the items conveys a 5-point scale, ranging from "never" to "every day"). Following Van der Velden and Bijlsma (2018), we compute a simple average of the six items indicating the use of numeracy skills at work. For the proficiency scores, we use the average of the ten plausible values (PVs) for each skill domain that are drawn from the proficiency distribution and provided in the PIAAC dataset (OECD, 2013, 2016). We leave out the $1^{\text {st }}$ and $99^{\text {th }}$ percentile of the distribution to avoid outliers. As a robustness check, we compute the results for several separate PVs to see whether they produce the same results, which is indeed the case (see Tables A4a-c in the online supplement Appendix A).

We dichotomise all our dependent variables in order to ensure comparability between our models. The first outcome under study - job satisfaction - is not normally distributed, which is why we cannot use the metric scale. Besides, factors that make worker satisfied may differ from those that make workers dissatisfied. We therefore predict satisfaction as opposed to no satisfaction. In PIAAC, the original variable that captures political efficacy is based on a 5-point scale ranging from "disagreement" to "agreement" with the statement "People like me don't have any say about what the government does". The category "neither agree nor disagree" does not seem to represent the indifferent middle in a continuum but rather must be interpreted as "don't know". We dichotomise the variable, predicting disagreement with the statement vs. the rest. Social trust is based on the sum score of two five-level Likert items on the perception of general trustworthiness of people. We dichotomise this variable, distinguishing between high social trust (sum scores $>5$ ) and low social trust (sum scores $<=5$ ). For sample statistics, see Table 1.

Our dataset contains individuals nested in sampling clusters (characterised by a specific weighting procedure) nested in countries. To properly take into account country-level errors, we estimate multilevel mixed-effects logit regression models (using the melogit command in Stata 14). Computing multilevel models, we cannot make use of the replicate weights that are implemented in PIAAC. All analyses are therefore weighted using a 'rescaling to cluster size' approach with which we adjust the overall sample weight to account for different sizes of the country samples. We assign a random effect on the cluster level as well as on the country level (for detailed information about the dataset and technical issues, see OECD, 2013 and 2016). We conduct deviance tests to evaluate the correct fit of our statistical models. The difference in deviance between nested models fitted to the same dataset can be used as test statistics having a chisquared distribution with the number of added parameters indicating the degrees of freedom (Snijders and Bosker, 2012: 97). Our empirical strategy follows Van der Velden and Bijlsma (2018). We first conduct some interim analyses, testing the effective skill assumption by 
comparing models in which we take up skill proficiency and skill use as separate variables to models in which we additionally include the effective skill interaction term that represents the multiplicative function of skill proficiency and skill use (for results, see Table A1 in the online Appendix A). We also run quantile regressions to assess whether the effect of skill use is the same over the entire skills distribution and the other way around (Figures 1-3).

In our main analyses, we estimate matching models to investigate the relation between effective skill and social outcomes based on the following formula:

$Y_{\mathrm{ic}}=\alpha_{\mathrm{c}}+\beta_{1} \mathrm{RES}_{\mathrm{ic}}+\beta_{2} \mathrm{OES}_{\mathrm{ic}}+\beta_{3} \mathrm{UES}_{\mathrm{ic}}+\beta_{4} \mathrm{C}_{\mathrm{ic}}+v_{\mathrm{ic}}+\omega_{\mathrm{ic}}$

or

$\mathrm{Y}_{\mathrm{ic}}=\alpha_{\mathrm{c}}+\beta_{1} E S M_{i c}+\beta_{2} \mathrm{C}_{\mathrm{ic}}+\mathrm{v}_{\mathrm{ic}}+\omega_{\mathrm{ic}}$

where $Y_{i c}$ is the outcome under study of individual $i$ in country $c ; \alpha_{c}$ is the country-specific constant; $\mathrm{ESM}_{\mathrm{ic}}$ is a vector of the three effective skill match variables: Required Effective Skill RES $_{i c}$, Overperformance in Effective Skill OES ic, and Underperformance in Effective Skill UES ic $_{\text {; }}$ $\mathrm{C}_{\mathrm{ic}}$ is a vector of control variables (containing age and age squared) ${ }^{3}$. The idiosyncratic error term at the individual level is represented by $v_{\text {ic }}$ whereas $\omega_{\text {ic }}$ refers to the country-level error term.

We compare the effective skill matching model with alternative skill mismatch models as suggested by Allen, Levels and Van der Velden (2013), and by Pellizzari and Fichen (2013). Allen et al. (2013) compare the individual skill use to the individual skill proficiency, capturing the relative skill use and the amount of over- and underutilisation of skills. By contrast, Pellizzari and Fichen (2013) assess the range of skill proficiency of all workers who identify themselves as wellmatched. Every respondent with a skill proficiency level above $95 \%$ of the proficiency range of the well-matched, is defined as overskilled, whereas every respondent below the $5 \%$ level is considered as underskilled (Pellizzari and Fichen, 2013). In addition to these alternative (objective) skill mismatch approaches, we include the subjective skill mismatch measure that is implemented in PIAAC.

We follow the classical ORU model approach by Duncan and Hoffman (1981). This model distinguishes three separate components: number of years of required education, number of years of overeducation, and number of years of undereducation. Following this approach, we turn all models into standard matching models containing these three components. The effective skill

\footnotetext{
${ }^{3}$ Controlling for age and age squared, we make sure that the natural driven effect of the cognitive decline in skills does not bias our findings. We do not include other controls to avoid over-controlling. Particularly, we do not control for the level of education as this is highly correlated with skills itself.
} 
matching model contains all three components. As the approaches by Allen et al. (2013) and Pellizzari/Fichen (2013) only identify underutilisation/overskilling and overutilisation/underskilling, we have to complement these models with a component that indicates job requirements. Using PIAAC data, the best proxy for skill requirements that we have is skill use. We therefore control for skill use to proxy skill requirements of jobs. For these alternative models based on Allen et al. (2013) and Pellizzari/Fichen (2013), we estimate the following equation, using the respective mismatch indicators.

$\mathrm{Y}_{\mathrm{ic}}=\alpha_{\mathrm{c}}+\beta_{1} \mathrm{SU}_{\mathrm{ic}}+\beta_{2} \mathrm{OS}_{\mathrm{ic}}+\beta_{3} \mathrm{US}_{\mathrm{ic}}+\beta_{4} \mathrm{C}_{\mathrm{ic}}+v_{\mathrm{ic}}+\omega_{\mathrm{ic}}$

where $\mathrm{SU}_{\mathrm{ic}}$ is the individual skill use score, and $\mathrm{OS}_{\mathrm{ic}}$, and $\mathrm{US}_{\mathrm{ic}}$ indicate overskilling and underskilling respectively.

As outlined above, we also compare our results with the subjective skill mismatch measure in PIAAC that is based on a direct self-assessment. We define employees as underskilled if they answer 'yes' to the question "Do you feel that you need further training in order to cope well with your present duties?" and 'no' to the question "Do you feel that you have the skills to cope with more demanding duties than those you are required to perform in your current job?”. By contrast, we define workers as overskilled if they answer the opposite to both questions. Following the approach developed by the OECD (2013), self-reported well-matched people are respondents who answer "no" to both questions. We use this category as a reference. A large number of people reported that they are underskilled as well as overskilled, a combination that is not interpretable. We will include this category in our models but will not interpret the results. Based on the self-assessment, the category "well-matched" is very small, containing only around 8 percent of all male full-time employees. ${ }^{4}$

Computing logistic multilevel mixed-effects models, we compare the odds of being in one group versus the other. To achieve a better comparison of the models, based on the alternative mismatch indicators (see Tables 2-4 and A5), we standardise all continuous independent variables (i.e. the effective skill variables and skill use) that we use in our statistical models. Only then can we directly compare the effect sizes of the different variables in the model. The mismatch indicators developed by Allen et al. (2013) and Pellizzari and Fichen (2013) are dummy variables, which is why we do not to standardise these variables.

\footnotetext{
${ }^{4}$ This is problematic when it comes to giving a good description of the distribution of skill matches and mismatches in the different countries. This variable should therefore not be used for descriptive analyses. However in our case we are more interested in the effect of subjective overskilling or underskilling. These results are probably less biased.
} 


\section{Findings}

Applying the effective skill matching model, we start our empirical analyses with a test of the underlying assumption that the outcome under study is a multiplicative term (see Van der Velden and Bijlsma, 2018). We perform quantile regressions to assess whether the association between the two components of effective skill, skill proficiency and skill use, and the outcomes under study is the same over the entire distribution and the other way around. Figures 1 to 3 are graphical representations of the results. Coefficients are obtained using weighted multilevel mixed-effects ordered logistic regressions (for further basic analyses, see Table A1 in the online appendix).

\section{[FIGURES 1 to 3 about here]}

For job satisfaction (see Figure 1), the graph shows that skill use has an overall significant and positive relation, no matter how proficient a worker is, whereas job satisfaction does not vary with skill proficiency. Although the existing literature on the relation between job satisfaction and skills does usually not differ between skill proficiency and skill use, this finding is unexpected. Using regression analyses, we will test later on if the alternative skill mismatch measures by Allen et al. (2013) and Pellizzari/Fichen (2013) give different results. By contrast to job satisfaction, the graphs for political efficacy (Figure 2) and social trust (Figure 3) show nearly smooth surfaces, clearly displaying a multiplicative effect. Both graphs represent the idea behind the effective skill concept, namely that the effects on social outcomes are a multiplicative function of skill proficiency and skill use.

Testing the hypotheses that we outlined before, we now compute matching models to examine the relation between skill mismatches, job satisfaction, political efficacy, and social trust as dependent variables. All tables display odds ratios. The interpretation is as follows: The number 1 is the centre of the odd scale. An odds ratio $<1$ implies that the chances are smaller compared to the reference category. An odds ratio $>1$ stands for a relative increase of chances to belong to the outcome group under study. An odds ratio $=1$ implies no differences in the chances of the two groups. For job satisfaction, results are displayed in Table 2.

\section{[TABLE 2 about here]}

Regarding the likelihood ratio test, the effective skill matching model (see model 1 in Table 2) performs clearly better than the alternative skill mismatch models 2 and 3. However, given that we already know from Figure 1 that the assumption of a multiplicative effect of skill proficiency and skill use on job satisfaction does not hold, we have to be cautious with the interpretation of 
the results. The results indicate that - in line with Hypothesis 1 - there is a relative strong effect of the level of required effective skill on job satisfaction: workers in jobs that require more effective skill are also more satisfied with their job. An increase in required effective skill of 1 standard deviation increases the chances of being satisfied with your job with $29 \%$. However, deploying more effective skill than required does not decrease the satisfaction level. For the alternative skill mismatch measures developed by Allen et al. (2013) and Pellizzari and Fichen (2013), we find positive and significant associations of skill use (as a proxy for required skills) and job satisfaction, thus again confirming Hypothesis 1 . However we do not find any support for an effect of being overskilled, which means that we have to refuse Hypothesis 2. Although we did not formulate any specific hypothesis on this, we do find a negative effect of being underskilled in the Allen et al. model. However, this relation is only significant at the $5 \%$ level. ${ }^{5}$

These are important findings. No matter which objective measure we use - the Allen et al. (2013) measure, Pellizzari/Fichen (2013) or our own effective skill matching model -, we do not find a correlation between being overskilled and job satisfaction ${ }^{6}$. This is contrary to what has been shown before, but that is because these previous findings were based on a subjective measure of skill mismatch. If we look at the subjective measure of skill mismatch available in PIAAC (model 4 in Table 2), we also find the expected negative effect of being overskilled. Moreover, the results also indicate a negative effect of being underskilled, although only significant at the $5 \%$ level. It thus seems that previous results on the relation between overskilling and job satisfaction, are only true when we measure skill mismatch in a subjective way. In other words, workers seem to become dissatisfied when they think that they can handle more complex jobs. However, on the basis of this observation we cannot make any claim about the effect of real skill mismatch based on objective indicators. An investigation of real skill (mis)match must always be based on objective information about a worker's real skill proficiency. Drawing on such objective measurements as provided by PIAAC, our findings indicate that the claim that earlier studies made regarding the negative correlation between overskilling and job satisfaction, is an artefact

\footnotetext{
5 This finding is contrary to the results of the original study by Allen et al. (2013), as the authors found that mismatched, and especially underutilised workers are less satisfied. The difference between the article at hand and the original study lies in the model specification: Allen et al. control for proficiency, whereas we control for skill use, following the classical Duncan and Hoffman (1981) specification. We also computed the model controlling for skill proficiency instead of skill use, and obtained the same negative effect of skill mismatches on job satisfaction that Allen et al. found. The authors agreed that the results related to the negative effect of mismatches were entirely driven by skill use.

${ }^{6}$ In addition to the outlined analyses, we tested the relation between education mismatches and the outcomes under study. Even there we do not find an association between mismatches and job satisfaction. Results are available upon request.
} 
because the mismatch measures are not based on reliable and objective skill proficiency indicators. To scrutinise this finding, we repeat the analyses for young entrants to the labour markets only. Even then, there is no association between overskilling and job satisfaction (see Table A5 in Appendix A).

We now look at the results for political efficacy, displayed in Table 3.

\section{[TABLE 3 about here]}

Model 1, the effective skill matching model, confirms our bypotheses 1 and 3, indicating that the level of required effective skill is indeed associated with political efficacy. As expected, required effective skill shows a positive relation with perceived political efficacy. An increase in required effective skill of 1 standard deviation increases the chances of belonging to the group of respondents who consider themselves and others efficacious on political issues with $74 \%$. Regarding overperformance, our hypotheses are also supported: 1 standard deviation increase in overperformance increases the chances for perceived political efficacy by $20 \%$. In line with our expectations, underperformance is negatively related to political efficacy. ${ }^{7}$

The alternative skill mismatch models by Allen et al. (2013) and Pellizzari/Fichen (2013) show similar results, except the fact that the coefficient for underskilling is not significant in the Pellizzari/Fichen-model. We find that skill use, as a proxy for skills requirements in the job, has a strong and positive relation to perceived political efficacy in both alternative models, although it is a little stronger in the Allen et al. (2013) model than in the Pellizzari/Fichen (2013) model. Comparing the results for over- and underskilling, we find that overskilling is positively related to political efficacy, whereas underskilling shows a negative relation. However, we cannot compare the effect sizes directly, because the indicators for over- and underskilling in the alternative models are dummy variables, whereas the comparable indicators for the effective skill matching model are standardised continuous variables. If we normalise the dummy variables, we find that the effect sizes are smaller than for the effective skill matching model. For example, the normalised indicator for overskilling in the Allen et al. model has a standardised odds ratio of

\footnotetext{
7 We use a continuous scale based on the amount of overperformance or underperformance respectively. Our findings are in line with Van der Velden and Verhaest (2017), showing that the first bit of skills shortage is positive, before the effects turn negative. However, the authors show that the negative part of the effect is linear. Overskilling seems to be a linear effect over the whole scale. To further check the relevance of the issue of non-linear effects for our analyses, we perform a robustness check, in which we include a quadratic term in the effective skill matching model (Model 1 in Tables 2, 3, and 4). The result of these additional analyses show no effects of the squared terms, no matter which dependent variable we use. We therefore do not look for further non-linearity.
} 
1.10 whereas the variable that indicates overperformance in the effective skill matching model has an odds ratio of 1.20 (results available upon request). We conclude that in general, the effect sizes that we obtain using the effective skill matching model are quite large ${ }^{8}$. Regarding the likelihood ratio test, the effective skill matching model performs better than the alternative skill mismatch models.

The last model (4) displays the results obtained using a subjective measure. We find no effect for the perception of being overskilled and a positive instead of a negative effect for subjective underskilling.

\section{[TABLE 4 about here]}

Last, we look at the results for social trust, which are displayed in Table 4. Again, we find support for our bypotheses 1 and 3. The effective skill matching shows a strong and positive relation between required effective skill as well as overperformance and social trust, and a negative relation with underperformance ${ }^{9}$. The model developed by Allen et al. (2013) gives similar results. In the model developed by Pellizzari and Fichen (2013), we only find a positive effect of overskilling at the $10 \%$ level, while there is no significant effect of being underskilled. Among the alternative skill mismatch models, the effective skill matching model shows the strongest likelihood ratio test. The results of model 4 based on the subjective indicator show no effect of mismatches. We conclude that social trust, although primarily related to proficiency and educational level, is also increased by the positive (and potentially empowering) experience caused by the utilisation of one's skills and talent.

\section{Conclusion}

Skill mismatch is claimed to have major consequences for societies and individuals, although convincing evidence mainly exists for wages (e.g. OECD, 2017). However, it is not all about money: There are indications that workers may suffer from dissatisfaction, and that both skills and mismatches may affect job satisfaction but also other aspects of private and social life, as they are associated, for example, with ideas about one's impact on political processes as well as general trust in other people. The relation between proficiency, skills and the mentioned social

\footnotetext{
8 Regression analyses that we conducted using an ORU model for education mismatches show similar results, providing further support for our hypotheses. However, the negative relation with undereducation is clearly smaller than the negative relation with underperformance (results available upon request).

9 The additional analyses that we perform using an ORU model for education mismatches point in the same direction (results available upon request).
} 
outcomes is established in the literature (see e.g. McMahon, 2009). Social outcomes, such as job satisfaction, political efficacy, and social trust are not only important for individual well-being, but, in aggregate, also for the way in which labour markets and societies function. However, if skills are important, and returns to skills are flexible regardless of formal job requirements, then skill mismatch (i.e. skills shortage or surplus) must also have an effect. Investigating job satisfaction and other social outcomes, our article addresses a topic of public, academic and political concern that has been identified as missing in the discourse on skill mismatch. We furthermore contribute to sociological research by using and testing a new approach to measure skill mismatch: the 'effective skill' concept, developed by Van der Velden and Bijlsma (2018). In our article, we relate this new measure to social outcomes, comparing the results with alternative indicators. We draw on PIAAC data, the first study to provide detailed data on workers' actual skills, and skill utilisation for representative samples of the work force of a large number of countries. Using the unprecedented possibilities provided by these data, our analyses are based on objective skills measurements for representative samples of male fulltime working employees in 22 OECD countries.

We provide empirical evidence for two important messages, the first of which is that skill mismatch is not related to job satisfaction. Previous studies find negative effects of mismatches, and especially overeducation/overskilling, on job satisfaction. We prove that on the basis of objective indicators - making use of all alternative measures that we currently have - skill mismatch does not have an impact, as job satisfaction is in fact driven by skills utilisation. People feel satisfied if they do things, especially if they do things they are good at. The claim that former studies make regarding negative associations of skill mismatches with job satisfaction, is merely based on subjective assessments of the skill match. To actually measure skill mismatch, both detailed knowledge about a worker's real skill proficiency and skill requirements of jobs is required. As this information is only provided by PIAAC for a large number of countries, previous studies could not assess the objective skill mismatch. Job satisfaction is a subjective indicator and, therefore, influenced by the subjective evaluation of one's own situation compared to what a worker expected for himself compared to others. However, the correlation between different subjective measures, such as the subjective assessment of job satisfaction and the selfassessment of a skill (mis-)match, is endogenous, and does not tell us much about the effect of real, objective over- and underskilling. Deploying unprecedented opportunities of the PIAAC data, we find that there is no relation between objective skill mismatch and job satisfaction, not even if we look at young entrants to the labour market only. The relation between skills and job satisfaction is driven by the use of skills: Job satisfaction is clearly not a mismatch story. 
The second message that we provide empirical evidence for is that effective skill and skill mismatches are related to other social outcomes such as political efficacy and social trust. Controlling for the requirements of a job, a surplus in skills or effective skill is positively related to social outcomes. Correspondingly, skill shortages and underperformance entail penalties. When it comes to explaining social outcomes, our findings and the deviance tests that we conducted suggest that the effective skill matching model is superior to existing skill mismatch models. This may have to do with the underlying conceptual proximity between effective skill and outcomes such as political efficacy, as the idea of combining proficiency and skill use in a multiplicative function has a conceptual link with efficacy theory (Bandura, 1977). Furthermore, effective skill is related to the concept of locus of control, which may in turn be related to political efficacy and social trust (Judge and Bono, 2001). However, we are still very much in the dark about the underlying mechanism. Nevertheless, what we observe leads us to the speculation that high proficiency combined with high skill use may serve as empowering combination, creating a stronger feeling of efficacy. Task-related efficacy may potentially increase perceived efficacy in other domains of life (Bandura, 1977). However, we cannot test these speculations empirically.

When it comes to non-employment-related social outcomes (such as political efficacy and social trust), applying a mismatch logic may not be too convincing at first glance. But we do find mismatch effects. Why this is, we do not know yet, but we consider the combination of skill proficiency and skill use to be an empowering combination. People who have skills and who can make use of skills may feel more in control and more efficacious in other domains of life too. Further research is necessary to examine the relation between skills, mismatches, and social outcomes as well as the relation with different dimensions and domains of satisfaction. Against the background of our findings, we are inclined to further explore the potential of PIAAC regarding the whole topic of social effects of skills and mismatches. We hope that the second cycle of the OECD Survey of Adult Skills (PIAAC) will widen the possibilities for in-depth research on the outlined topics. When it comes to explaining social outcomes, our findings clearly indicate that skill mismatches, and especially effective skill, are "much ado about something". 


\section{References}

Allen, J. and van der Velden, R. (2001). Educational mismatches versus skill mismatches: effects on wages, job satisfaction, and on-the-job search, Oxford Economic Papers, 3, 434-452.

Allen, J., Levels, M. and van der Velden, R. (2013). Skill mismatch and skill use in developed countries: Evidence from the PIAAC study, ROA Research Memorandum (ROA-RM2013/17), Maastricht: ROA.

Allen, J. and Bijlsma, I. (2015). Skill Profiles of Occupations: Robust Multi-level Estimates Based on PIAAC Data, Internal Memo, Maastricht: ROA.

Bandura, A. (1977). Self-efficacy: Toward a unifying theory of behavioural change, Psychological Review, 84(2), 191-215.

Borgonovi, F. and Burns, T. (2015). The educational roots of trust, OECD Education Working Papers, No. 119, Paris: OECD Publishing.

Büchel, F., de Grip, A. and Mertens, A. (Eds.) (2003). Overeducation in Europe. Current Issues in Theory and Policy. Cheltenham, UK, Northhampton, MA: E. Elgar.

Cedefop. (2018). Insights into skill shortages and skill mismatch. Learning from Cedefop's European skills and jobs survey. Luxembourg: Publications of the European Union.

Desjardins, R. and Schuller, T. (2006). Introduction: Understanding the Social Outcomes of Learning. In: Measuring the Effects of Education on Health and Civic Engagement. Proceedings of the Copenhagen Symposium, 1-18, Paris: OECD.

Duncan, G.J. and Hoffman, S.D. (1981). The incidence and wage effects of overeducation, Economics of Education Review 1 (1), 75-86.

European Commission. (2016). A New Skills Agenda for Europe. Communication from the Commission to the European Parliament, The Council, The European Economic and Social Committee and The Committee of the Regions.

Freeman, R. (1976). The Overeducated American. New York: Academic Press.

Green, F. (2013). Skills and skilled work - An Economic and Social Analysis, Oxford: Oxford University Press.

Green, F. and Henseke, G. (2016). Should governments of OECD countries worry about graduate underemployment?, ECOPOL, 32 (4), 514-537. 
Green, F. and Zhu, Y. (2010). Overqualification, job dissatisfaction, and increasing dispersion in the returns to graduate education, Oxford Economic Papers, 62 (4), 740-763.

Green, F., Felstead, A., Gallie, D. and Inanc, H. (2013). Job-Related Well-Being in Britain: First Findings from the Skills and Employment Survey 2012. London: Centre for Learning and Life Chances in Knowledge Economies and Societies, Institute of Education.

Groot, W. and Maassen van den Brink, H. (2000). Overeducation in the labor market: a metaanalysis, Economics of Education Review, 19(2), 149-158

Hanushek, E.A., Schwerdt, G., Wiederhold, S. and Woessmann, L. (2015). Returns to skills around the world: Evidence from PIAAC, European Economic Review, 73 (2015), 103-130.

Hanushek, E.A. and Woessmann, L. (2015). The knowledge capital of nations: Education and the economics of growth. Cambridge (MA): MIT Press.

Hartog, J. (2000). Overeducation and Earnings: Where Are We, Where Should We Go?, Economics of Education Review, 19, 131-147.

Heyes, J., Tomlinson, M. and Whitworth, A. (2017). Underemployment and well-being in the UK before and after the Great Recession, Work, employment and society, 31(1), 71-89.

Judge, T.A and Bono, J.E. (2001). Relationship of core self-evaluations traits - self-esteem, generalised self-efficacy, locus of control and emotional stability - with job satisfaction and job performance, Journal of Applied Psychology, 86 (1), 80-92.

McMahon, W.W. (2009). Higher Learning - Greater Good. The Private and Social Benefits of Higher Education, Baltimore: The Job Hopkins University Press.

OECD. (2013). The Survey of Adult Skills: Reader's companion. Paris: OECD Publishing.

OECD. (2016). Technical report of the Survey of Adult Skills (PLAAC) (2 $2^{\text {nd }}$ Edition). Paris: OECD Publishing.

OECD. (2017). OECD Skills Outlook 2017: Skills and Global Value Chains. Paris: OECD Publishing.

Pellizzari, M. and Fichen, A. (2013). A New Measure of Skills Mismatch, Theory and Evidence from the Survey of Adult Skills (PIAAC), OECD Social, Employment and Migration Working Papers, No. 153, Paris: OECD Publishing.

Perry, A., Wiederhold, S. and Ackermann-Piek, D. (2014). How Can Skill Mismatch be Measured? New Approaches with PIAAC, Methods, data, analyses, 8 (2), 137-174. 
Polachek, S. W., Pouliakas, K., Russo, G. and Tatsiramos, K. (Eds.) (2017). Skill Mismatch in Labor Markets, Research in Labor Economics, 45, Emerald Publishing Limited.

Salthouse, T. (2006). Mental exercise and mental ageing: Evaluating the validity of the "use it or lose it" hypothesis, Perspectives on Psychological Science, 1 (1), 68-87.

Schleicher, A. and Thorn, W. (2016). Proposal for an extended module of non-economic outcomes in the second cycle of PIAAC. Internal Memo; Paris: OECD.

Sloane, P.J. (2003). Much ado About Nothing? What does the Overeducation Literature Really Tell us? In: Büchel, F., de Grip, A. and Mertens, A. (Eds.): Overeducation in Europe. Current Issues in Theory and Policy. Cheltenham, UK, Northhampton, MA: E. Elgar, 11-48.

Snijders, T. and Bosker, R.J. (2012). Multilevel Analysis. An Introduction to Basic and Advanced Multilevel Modeling. 2nd Edition. Los Angeles: Sage.

Van der Velden, R. and Bijlsma, I. (2018). Effective skill: A new theoretical perspective on the relation between skills, skill use, mismatches, and wages. Oxford Economic Papers 2018, to appear.

Van der Velden, R. and Verhaest, D. (2017). Are Skill Deficits always Bad? Toward a Learning Perspective on Skill Mismatches. In: Polachek, S. W., Pouliakas, K., Russo, G. and Tatsiramos, K. (Eds.) Skill Mismatch in Labor Markets, Research in Labor Economics, Volume 45, Emerald Publishing Limited, pp. 305-343.

Verhaest, D. and van der Velden, R. (2013). Cross-country Differences in Graduate Overeducation, European Sociological Review, 29 (3), 642-653.

Verhaest, D. and Verhofstadt, E. (2016). Overeducation and job satisfaction. The role of job demands and control, Int J of Manpower, 37 (3), 456-47.

Voßemer, J. and Schuck, B. (2016). Better Overeducated than Unemployed? The Short- and Long-Term Effects of an Overeducated Labour Market Re-entry, European Sociological Review, 32 (2), 251-265. 


\section{Appendix}

\section{TABLE 1 - SAMPLE DESCRIPTIVES}

\begin{tabular}{|c|c|c|c|c|c|c|c|c|c|c|}
\hline \multirow[b]{2}{*}{ Dependent variable } & \multirow[b]{2}{*}{ Binary outcomes } & \multicolumn{2}{|c|}{ TOTAL } & \multicolumn{3}{|c|}{ Age groups } & \multicolumn{4}{|c|}{ Education level } \\
\hline & & Freq. & Percent & $\begin{array}{c}\text { Entry age } \\
(16-34)\end{array}$ & $\begin{array}{c}\text { Prime age } \\
(35-49)\end{array}$ & $\begin{array}{c}\text { Major age } \\
(50-65)\end{array}$ & Compulsory & Secondary & Tertiary & Missing \\
\hline \multirow{3}{*}{$\begin{array}{l}\text { Job satisfaction } \\
\text { (1) }\end{array}$} & Satisfied (1) & 25,876 & 79.90 & 8,837 & 9,949 & 7,090 & 3,881 & 15,084 & 6,903 & 8 \\
\hline & Not satisfied (0) & 6,492 & 20.05 & 2,479 & 2,505 & 1,508 & 944 & 3,975 & 1,570 & 3 \\
\hline & Missing (.) & 19 & 0.06 & 2 & 4 & 13 & 1 & 1 & 10 & 0 \\
\hline \multirow{3}{*}{$\begin{array}{l}\text { Political Efficacy } \\
\text { (2) }\end{array}$} & Disagree (1) & 17,146 & 52.94 & 6,022 & 6,682 & 4,442 & 1,938 & 9,537 & 5,667 & 4 \\
\hline & Agree (0) & 15,096 & 46.61 & 5,232 & 5,735 & 4,129 & 2,841 & 9,465 & 2,784 & 6 \\
\hline & Missing (.) & 145 & 0.45 & 64 & 41 & 40 & 47 & 65 & 32 & 1 \\
\hline \multirow{3}{*}{$\begin{array}{l}\text { Social Trust } \\
\text { (3) }\end{array}$} & $\begin{array}{l}\text { High generalized } \\
\text { trust (1) }\end{array}$ & 9,822 & 30.33 & 3,044 & 3,931 & 2,847 & 1,032 & 5,034 & 3,754 & 2 \\
\hline & $\begin{array}{l}\text { Low generalized } \\
\text { trust }(0)\end{array}$ & 22,482 & 69.42 & 8,241 & 8,502 & 5,739 & 3,769 & 13,997 & 4,708 & 8 \\
\hline & Missing (.) & 83 & 0.26 & 33 & 25 & 25 & 25 & 36 & 21 & 1 \\
\hline
\end{tabular}

(1) Binary item that distinguishes between respondents that are 'satisfied' or 'extremely satisfied' with their current job (=1) vs. rest (=0)

(2) Binary item that distinguishes between respondents who disagree ( $=1$ ) to the statement 'People like me don't have any say about what the government does' vs. those that agree $(=0)$

(3) Dichotomised sum score over two five-level Likert items on the perception of general trustworthiness of people (sum score 6-10 (=1) vs. sum score 2-5 (=0)) 
FIGURES 1 TO 3 - QUANTILE REGRESSION: EFFECTS OF INCREASING ONE QUINTILE IN NUMERACY SKILL OR NUMERACY USE

Figure 1: Job satisfaction

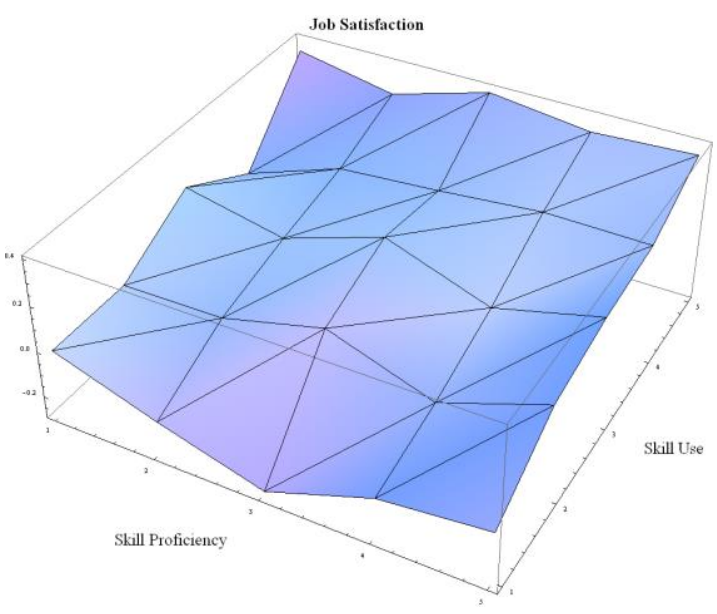

Figure 3: Social Trust

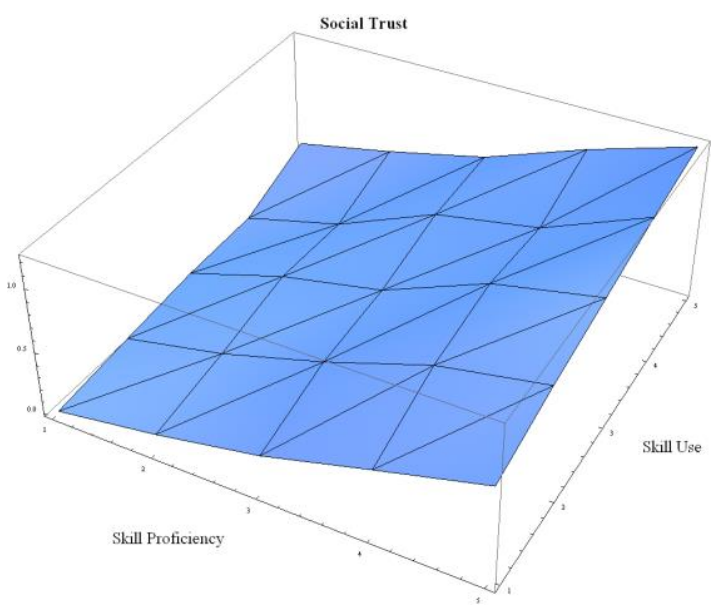

Figure 2: Political Efficacy

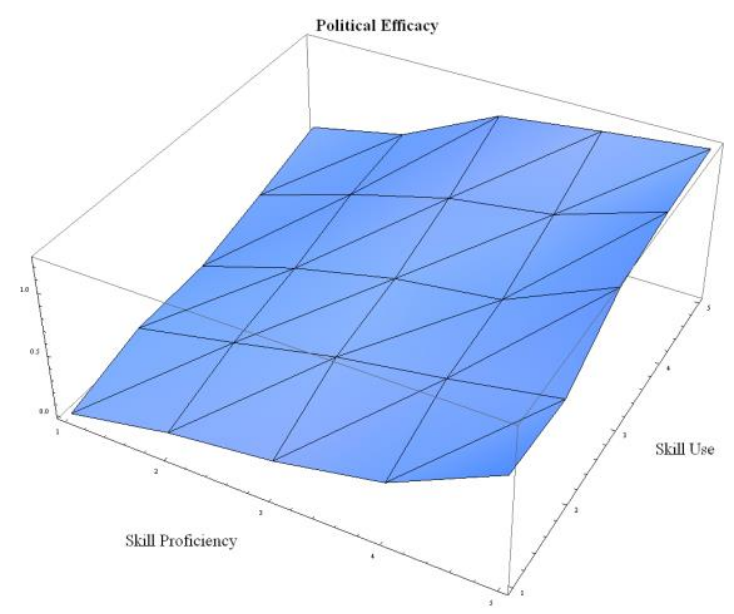


TABLE 2 - COMPARISON OF MISMATCH INDICATORS; DV: JOB SATISFACTION

Odds ratios based on multilevel mixed-effects logistic regression models, standard errors in parentheses;

All continuous independent variables are standardised with std(1) and mean(0)

\begin{tabular}{|c|c|c|c|c|}
\hline VARIABLES & $\begin{array}{c}\text { Model } 1 \\
\text { Effective skill } \\
\text { matching model } \\
\text { (2018) }\end{array}$ & $\begin{array}{c}\text { Model } 2 \\
\text { Allen et al. } \\
(2013)\end{array}$ & $\begin{array}{c}\text { Model } 3 \\
\text { Pellizzari \& } \\
\text { Fichen (2013) }\end{array}$ & $\begin{array}{c}\text { Model } 4 \\
\text { Direct self- } \\
\text { assessment }\end{array}$ \\
\hline
\end{tabular}

Required effective skill (std)

$1.2895^{* * *}$

(0.0476)

Overperformance effective skill (std)

0.9930

(0.0220)

Underperformanc effective skill (std)

0.9623

(0.0238)

Skill use (D. = Dummy)

Overskilled (Allen et al) (D.)

Underskilled (Allen et al) (D.)

Overskilled (Pellizzari/Fichen) (D.)

$1.1901^{* * *}$

(0.0320)

0.9663

(0.0773)

$0.8565^{* *}$

(0.0563)

0.9338

(0.0658)

1.1177

(0.0757)

Required Education (ORU) (std)

Overeducation (ORU) (std)

Undereducation (ORU) (std)

Overskilled according to DSA (D.)

$0.6692 * * *$

(0.0601)

Underskilled acc. to DSA (D.)

$0.7695^{* *}$

(0.0858)

Mixed acc. to DSA (D.)

$0.8302 * *$

(0.0726)

\begin{tabular}{|c|c|c|c|c|}
\hline $\mathrm{N}_{\text {individuals }}$ & 32,368 & 32,368 & 31,947 & 32,121 \\
\hline $\mathrm{N}_{\text {countries }}$ & 22 & 22 & 22 & 22 \\
\hline Likelihood ratio test & Model 1 & Model 2 & Model 3 & Model 4 \\
\hline log likelihood & -15393 & -15442 & -15233 & -15284 \\
\hline Deviance $^{1}\left(D_{i}\right)$ & 30786 & 30884 & 30466 & 30568 \\
\hline $\begin{array}{l}\text { Decrease in deviance compared to } \\
\text { Intercept model }\left(D_{0}-D_{i}\right)^{2}\end{array}$ & 222 & 124 & 116 & 190 \\
\hline Degrees of freedom & $(d f=3)$ & $(d f=3)$ & $(d f=3)$ & $(d f=4)$ \\
\hline Chi-squared value & $\mathrm{p}<0.005^{* * *}$ & $\mathrm{p}<0.005^{* * *} \quad \mathrm{p}<0.005^{* * *}$ & & $\mathrm{p}<0.005^{* * *}$ \\
\hline
\end{tabular}

All figures are weighted; Controls include age, age2; ${ }^{* * *} p<0.01, * * p<0.05, * p<0.1$

${ }^{1}$ Deviance $=-2^{*}($ log likelihood $)$, see Snijders and Bosker, 2012: 97ff.

${ }^{2}$ The decrease in deviance is computed based on the specific intercept model of each mismatch-approach 
TABLE 3 - COMPARISON OF MISMATCH INDICATORS; DV: POLITICAL EFFICACY

Odds ratios based on multilevel mixed-effects logistic regression models, standard errors in parentheses;

All continuous independent variables are standardised with std(1) and mean(0)

\begin{tabular}{|c|c|c|c|c|}
\hline VARIABLES & $\begin{array}{c}\text { Model } 1 \\
\text { Effective skill } \\
\text { matching } \\
\text { model (2018) }\end{array}$ & $\begin{array}{l}\text { Model } 2 \\
\text { Allen et al. } \\
\text { (2013) }\end{array}$ & $\begin{array}{c}\text { Model } 3 \\
\text { Pellizzari \& } \\
\text { Fichen (2013) }\end{array}$ & $\begin{array}{c}\text { Model } 4 \\
\text { Direct self- } \\
\text { assessment }\end{array}$ \\
\hline Required effective skill (std) & $\begin{array}{c}1.7373 * * * \\
(0.0682)\end{array}$ & & & \\
\hline Overperformance effective skill (std) & $\begin{array}{c}1.2023 * * * \\
(0.0232)\end{array}$ & & & \\
\hline Underperformance effective skill (std) & $\begin{array}{c}0.8246 * * * \\
(0.0172)\end{array}$ & & & \\
\hline Skill use (D. = Dummy) & & $\begin{array}{c}1.5077^{* * *} \\
(0.0435)\end{array}$ & $\begin{array}{c}1.3949 * * * \\
(0.0324)\end{array}$ & $\begin{array}{c}1.3883^{* * *} \\
(0.0292)\end{array}$ \\
\hline Overskilled (Allen et al) (D.) & & $\begin{array}{c}1.4533^{* * *} \\
(0.1251)\end{array}$ & & \\
\hline Underskilled (Allen et al) (D.) & & $\begin{array}{c}0.5807^{* * *} \\
(0.0388)\end{array}$ & & \\
\hline Overskilled (Pellizzari/Fichen) (D.) & & & $\begin{array}{c}1.2096 * * * \\
(0.0777)\end{array}$ & \\
\hline Underskilled (P./F.) (D.) & & & $\begin{array}{c}0.9191 \\
(0.0632)\end{array}$ & \\
\hline Required Education (ORU) (std) & & & & \\
\hline Overeducation (ORU) (std) & & & & \\
\hline Undereducation (ORU) (std) & & & & \\
\hline Overskilled according to DSA (D.) & & & & $\begin{array}{c}1.0759 \\
(0.0635)\end{array}$ \\
\hline Underskilled acc. to DSA (D.) & & & & $\begin{array}{c}1.2263^{* * *} \\
(0.0819)\end{array}$ \\
\hline Mixed acc. to DSA (D.) & & & & $\begin{array}{c}1.2585^{* * *} \\
(0.1092)\end{array}$ \\
\hline $\mathrm{N}_{\text {individuals }}$ & 32,242 & 32,242 & 31,823 & 32,003 \\
\hline $\mathrm{N}_{\text {countries }}$ & 22 & 22 & 22 & 22 \\
\hline Likelihood ratio test & Model 1 & Model 2 & Model 3 & Model 4 \\
\hline log likelihood & -20381 & -20549 & -20361 & -20467 \\
\hline Deviance $^{1}\left(D_{i}\right)$ & 40762 & 41098 & 40722 & 40934 \\
\hline $\begin{array}{l}\text { Decrease in deviance compared to } \\
\text { Intercept model }\left(D_{0}-D_{i}\right)^{2} \\
\text { Degrees of freedom }\end{array}$ & $\begin{array}{c}1286 \\
(d f=3)\end{array}$ & $\begin{array}{c}950 \\
(\mathrm{df}=3)\end{array}$ & $\begin{array}{c}778 \\
(\mathrm{df}=3)\end{array}$ & $\begin{array}{c}792 \\
(\mathrm{df}=4)\end{array}$ \\
\hline Chi-squared value & $\mathrm{p}<0.005^{* * *}$ & $\mathrm{p}<0.005^{* * *}$ & $\mathrm{p}<0.005 * * *$ & $\mathrm{p}<0.005^{* * *}$ \\
\hline
\end{tabular}

All figures are weighted; Controls include age, age2; $* * * p<0.01, * * p<0.05, * p<0.1$

${ }^{1}$ Deviance $=-2^{*}(\log$ likelihood $)$, see Snijders and Bosker, 2012: $97 \mathrm{ff}$.

${ }^{2}$ The decrease in deviance is computed based on the specific intercept model of each mismatch-approach 
TABLE 4 - COMPARISON OF MISMATCH INDICATORS; DV: SOCIAL TRUST

Odds ratios based on multilevel mixed-effects logistic regression models, standard errors in parentheses;

All continuous independent variables are standardised with std(1) and mean(0)

\begin{tabular}{|c|c|c|c|c|}
\hline VARIABLES & $\begin{array}{c}\text { Model } 1 \\
\text { Effective skill } \\
\text { matching } \\
\text { model (2018) }\end{array}$ & $\begin{array}{c}\text { Model } 2 \\
\text { Allen et al. } \\
\text { (2013) }\end{array}$ & $\begin{array}{c}\text { Model } 3 \\
\text { Pellizzari \& } \\
\text { Fichen (2013) }\end{array}$ & $\begin{array}{c}\text { Model } 4 \\
\text { Direct self- } \\
\text { assessment }\end{array}$ \\
\hline Required effective skill (std) & $\begin{array}{c}1.7057^{* * *} \\
(0.0713)\end{array}$ & & & \\
\hline Overperformance effective skill (std) & $\begin{array}{c}1.1445^{* * *} \\
(0.0208)\end{array}$ & & & \\
\hline Underperformance effective skill (std) & $\begin{array}{c}0.8642^{* * *} \\
(0.0193)\end{array}$ & & & \\
\hline Skill use (D. = Dummy) & & $\begin{array}{c}1.4290 * * * \\
(0.0422)\end{array}$ & $\begin{array}{c}1.3243 * * * \\
(0.0324)\end{array}$ & $\begin{array}{c}1.3243^{* * *} \\
(0.0327)\end{array}$ \\
\hline Overskilled (Allen et al) (D.) & & $\begin{array}{c}1.6063 * * * \\
(0.1362)\end{array}$ & & \\
\hline Underskilled (Allen et al) (D.) & & $\begin{array}{c}0.6160 * * * \\
(0.0408)\end{array}$ & & \\
\hline Overskilled (Pellizzari/Fichen) (D.) & & & $\begin{array}{l}1.1393 * \\
(0.0775)\end{array}$ & \\
\hline Underskilled (P./F.) (D.) & & & $\begin{array}{c}1.0068 \\
(0.0513)\end{array}$ & \\
\hline Required Education (ORU) (std) & & & & \\
\hline Overeducation (ORU) (std) & & & & \\
\hline Undereducation (ORU) (std) & & & & \\
\hline Overskilled according to DSA (D.) & & & & $\begin{array}{c}0.9071 \\
(0.0618)\end{array}$ \\
\hline Underskilled acc. to DSA (D.) & & & & $\begin{array}{c}0.9999 \\
(0.0900)\end{array}$ \\
\hline Mixed acc. to DSA (D.) & & & & $\begin{array}{c}0.9841 \\
(0.0661)\end{array}$ \\
\hline$N_{\text {individuals }}$ & 32,304 & 32,304 & 31,885 & 32,058 \\
\hline$N_{\text {countries }}$ & 22 & 22 & 22 & 22 \\
\hline Likelihood ratio test & Model 1 & Model 2 & Model 3 & Model 4 \\
\hline log likelihood & -17584 & -17786 & -17663 & -17695 \\
\hline Deviance $^{1}\left(D_{i}\right)$ & 35168 & 35572 & 35326 & 35390 \\
\hline $\begin{array}{l}\text { Decrease in deviance compared to } \\
\text { Intercept model }\left(D_{0}-D_{i}\right)^{2}\end{array}$ & 1010 & 606 & 456 & 454 \\
\hline Degrees of freedom & $(\mathrm{df}=3)$ & $(d f=3)$ & $(\mathrm{df}=3)$ & $(\mathrm{df}=4)$ \\
\hline Chi-squared value & $p<0.005^{* * *}$ & $p<0.005^{* * *} \quad p<C$ & & $005^{* * *}$ \\
\hline
\end{tabular}

All figures are weighted; Controls include age, age2; *** $p<0.01,{ }^{* *} p<0.05, * p<0.1$

${ }^{1}$ Deviance $=-2^{*}(\log$ likelihood $)$, see Snijders and Bosker, 2012: $97 \mathrm{ff}$.

2 The decrease in deviance is computed based on the specific intercept model of each mismatch-approach 


\section{Appendix A (Supplemental Material): Robustness checks and additional analyses}

TABLE A1 - EXPLORING THE IMPACT OF SKILL PROFICIENCY, SKILL USE, AND EFFECTIVE SKILL; MULTILEVEL MIXED-EFFECTS LOGIT MODELS

\begin{tabular}{|c|c|c|c|c|c|c|}
\hline Model & 1 & 2 & 3 & 4 & 5 & 6 \\
\hline Dependent Variable & \multicolumn{2}{|c|}{ Job Satisfaction } & \multicolumn{2}{|c|}{ Political Efficacy } & \multicolumn{2}{|c|}{ Social Trust } \\
\hline Skill Proficiency & $\begin{array}{c}1.0138 \\
(0.0302)\end{array}$ & $\begin{array}{c}0.5423 * * * \\
(0.0793)\end{array}$ & $\begin{array}{c}1.3341^{* * *} \\
(0.0365)\end{array}$ & $\begin{array}{c}0.8754 \\
(0.1916)\end{array}$ & $\begin{array}{c}1.3730 * * * \\
(0.0452)\end{array}$ & $\begin{array}{c}0.8139 \\
(0.1239)\end{array}$ \\
\hline Skill Use & $\begin{array}{c}1.1721 * * * \\
(0.0210)\end{array}$ & $\begin{array}{c}0.6153^{* * *} \\
(0.0863)\end{array}$ & $\begin{array}{c}1.2627 * * * \\
(0.0244)\end{array}$ & $\begin{array}{c}0.8193 \\
(0.1782)\end{array}$ & $\begin{array}{c}1.1840 * * * \\
(0.0233)\end{array}$ & $\begin{array}{c}0.6931^{* *} \\
(0.1019)\end{array}$ \\
\hline $\begin{array}{l}\text { Skill Proficiency * Skill Use } \\
\text { (= Effective skill) }\end{array}$ & & $\begin{array}{c}1.0661^{* * *} \\
(0.0149)\end{array}$ & & $\begin{array}{l}1.0438^{* *} \\
(0.0224)\end{array}$ & & $\begin{array}{c}1.0542^{* * *} \\
(0.0151)\end{array}$ \\
\hline Observations & 32,368 & 32,368 & 32,242 & 32,242 & 32,304 & 32,304 \\
\hline Number of groups & 22 & 22 & 22 & 22 & 22 & 22 \\
\hline
\end{tabular}

Odd ratios and standard errors in parentheses; ${ }^{* *} p<0.01,{ }^{* *} p<0.05,{ }^{*} p<0.1$; Controls include age, age2; All figures are weighted

\begin{tabular}{|c|c|c|c|c|c|c|}
\hline \multirow{2}{*}{$\begin{array}{l}\text { Likelihood ratio test } \\
\text { log likelihood }\end{array}$} & \multicolumn{2}{|c|}{ Job Satisfaction } & \multicolumn{2}{|c|}{ Political Efficacy } & \multicolumn{2}{|c|}{ Social Trust } \\
\hline & -15445 & -15437 & -20448 & -20443 & -17679 & -17673 \\
\hline Deviance $^{1}\left(D_{i}\right)$ & 30890 & 30874 & 40896 & 40886 & 35358 & 35346 \\
\hline $\begin{array}{l}\text { Decrease in deviance } \\
\text { between nested models }\end{array}$ & & $\begin{array}{c}\mathrm{D}_{\mathrm{M} 7}-\mathrm{D}_{\mathrm{M} 8} \\
16\end{array}$ & & $\begin{array}{c}\mathrm{D}_{\mathrm{M} 1}-\mathrm{D}_{\mathrm{M} 2} \\
10\end{array}$ & & $\begin{array}{c}\mathrm{D}_{\mathrm{M} 5}-\mathrm{D}_{\mathrm{M} 6} \\
12\end{array}$ \\
\hline Chi-squared value of decrease (Nested models) & & $\mathrm{p}<0.005^{* * *}$ & & $\mathrm{p}<0.01 * * *$ & & $\mathrm{p}<0.01 * * *$ \\
\hline Degrees of freedom & & $\mathrm{df}=3$ & & $\mathrm{df}=3$ & & $\mathrm{df}=3$ \\
\hline
\end{tabular}

${ }^{1}$ Deviance $=-2^{*}(\log$ likelihood $)$, see Snijders and Bosker, 2012: 97ff. 
TABLE A2 - EXPLORING THE IMPACT OF SKILL PROFICIENCY, SKILL USE, AND EFFECTIVE SKILL - ROBUSTNESS CHECK USING THE LITERACY DOMAIN

\begin{tabular}{|c|c|c|c|c|c|c|c|c|c|}
\hline Model & 1 & 2 & 3 & 4 & 5 & 6 & 7 & 8 & 9 \\
\hline VARIABLES & Int. Model & $\begin{array}{l}\text { Job Satis- } \\
\text { faction }\end{array}$ & $\begin{array}{l}\text { Job Satis- } \\
\text { faction }\end{array}$ & Int. Model & $\begin{array}{l}\text { Political } \\
\text { Efficacy }\end{array}$ & $\begin{array}{l}\text { Political } \\
\text { Efficacy }\end{array}$ & Int. Model & $\begin{array}{l}\text { Social } \\
\text { Trust }\end{array}$ & $\begin{array}{l}\text { Social } \\
\text { Trust }\end{array}$ \\
\hline Skill Proficiency & & $\begin{array}{c}1.0012 \\
(0.0156)\end{array}$ & $\begin{array}{c}0.5563 * * * \\
(0.0879)\end{array}$ & & $\begin{array}{c}1.2469 * * * \\
(0.0209)\end{array}$ & $\begin{array}{c}0.5937 * * * \\
(0.0935)\end{array}$ & & $\begin{array}{c}1.2671^{* * *} \\
(0.0318)\end{array}$ & $\begin{array}{l}0.7126^{* *} \\
(0.1095)\end{array}$ \\
\hline Skill Use & & $\begin{array}{c}1.2556^{* * *} \\
(0.0241)\end{array}$ & $\begin{array}{c}0.7019 * * \\
(0.1075)\end{array}$ & & $\begin{array}{c}1.2532 * * * \\
(0.0325)\end{array}$ & $\begin{array}{c}0.6051^{* * * *} \\
(0.0889)\end{array}$ & & $\begin{array}{c}1.2127^{* * *} \\
(0.0195)\end{array}$ & $\begin{array}{l}0.6882^{* *} \\
(0.1045)\end{array}$ \\
\hline $\begin{array}{l}\text { Skill Proficiency * Skill Use } \\
\text { (= Effective skill) }\end{array}$ & & & $\begin{array}{c}1.0619 * * * \\
(0.0164)\end{array}$ & & & $\begin{array}{c}1.0780 * * * \\
(0.0170)\end{array}$ & & & $\begin{array}{c}1.0595 * * * \\
(0.0159)\end{array}$ \\
\hline Observations & 32,368 & 32,368 & 32,368 & 32,242 & 32,242 & 32,242 & 32,304 & 32,304 & 32,304 \\
\hline Number of groups & 22 & 22 & 22 & 22 & 22 & 22 & 22 & 22 & 22 \\
\hline
\end{tabular}

Odd ratios and standard errors in parentheses; ${ }^{* * *} p<0.01,{ }^{* *} p<0.05,{ }^{*} p<0.1$; Controls include age, age2; All figures are weighted

\begin{tabular}{|c|c|c|c|c|c|c|c|c|c|}
\hline Likelihood ratio test & Int. Model & $\begin{array}{l}\text { Job Satis- } \\
\text { faction }\end{array}$ & $\begin{array}{l}\text { Job Satis- } \\
\text { faction }\end{array}$ & Int. Model & $\begin{array}{l}\text { Political } \\
\text { Efficacy }\end{array}$ & $\begin{array}{l}\text { Political } \\
\text { Efficacy }\end{array}$ & Int. Model & $\begin{array}{l}\text { Social } \\
\text { Trust }\end{array}$ & $\begin{array}{l}\text { Social } \\
\text { Trust }\end{array}$ \\
\hline log likelihood & -15504 & -15387 & -15370 & -21024 & -20406 & -20370 & -18089 & -17612 & -17595 \\
\hline Deviance $^{1}\left(D_{i}\right)$ & 31008 & 30774 & 30740 & 42048 & 40812 & 40740 & 36178 & 35224 & 35190 \\
\hline $\begin{array}{l}\text { Decrease in deviance }\left(D_{0}-D_{i}\right) \\
\text { compared to Intercept model }\end{array}$ & & 234 & 268 & & 1236 & 1308 & & 954 & 988 \\
\hline Degrees of freedom & & $d f=2$ & $d f=3$ & & $\mathrm{df}=2$ & $d f=3$ & & $d f=2$ & $d f=3$ \\
\hline $\begin{array}{l}\text { Chi-squared value of decrease compared to Intercept } \\
\text { model }\end{array}$ & & $\begin{aligned} & \mathrm{p}<0.005 \\
& * * *\end{aligned}$ & $\begin{aligned} \mathrm{p} & <0.005 \\
* * * & \end{aligned}$ & & $\begin{aligned} \mathrm{p} & <0.005 \\
* * * & \end{aligned}$ & $\begin{aligned} & \mathrm{p}<0.005 \\
& * * *\end{aligned}$ & & $\begin{aligned} \mathrm{p} & <0.005 \\
* * * & \end{aligned}$ & $\begin{aligned} \mathrm{p} & <0.005 \\
& * * *\end{aligned}$ \\
\hline \multirow{2}{*}{ Additional decrease in deviance (Nested models) } & & & $\mathrm{D}_{\mathrm{M} 2}-\mathrm{D}_{\mathrm{M} 1}$ & & & $D_{M 6}-D_{M 5}$ & & & $\mathrm{D}_{\mathrm{M} 10}-\mathrm{D}_{\mathrm{M} 9}$ \\
\hline & & & 34 & & & 72 & & & 34 \\
\hline Chi-squared value of decrease (Nested models) & & & $\begin{array}{c}\mathrm{p}<0.005 \\
* * *\end{array}$ & & & $\begin{array}{c}\mathrm{p}<0.005 \\
* * *\end{array}$ & & & $\begin{aligned} & \mathrm{p}<0.005 \\
& * * *\end{aligned}$ \\
\hline Degrees of freedom & & & $d f=3$ & & & $d f=3$ & & & $d f=3$ \\
\hline
\end{tabular}

${ }^{1}$ Deviance $=-2 *(\log$ likelihood), see Snijders and Bosker, 2012: 97ff. 


\section{TABLE A3 - EfFECTIVE SKILL MATCHING MODEL - ROBUStNeSS CHECK USING THE LITERACY DOMAIN}

\begin{tabular}{|c|c|c|c|c|c|c|}
\hline Model & 1 & 2 & 3 & 4 & 5 & 12 \\
\hline VARIABLES & $\begin{array}{c}\text { Int. } \\
\text { Model }\end{array}$ & $\begin{array}{c}\text { Job } \\
\text { Satisfaction }\end{array}$ & $\begin{array}{c}\text { Int. } \\
\text { Model }\end{array}$ & $\begin{array}{l}\text { Political } \\
\text { Efficacy }\end{array}$ & $\begin{array}{c}\text { Int. } \\
\text { Model }\end{array}$ & $\begin{array}{l}\text { Social } \\
\text { Trust }\end{array}$ \\
\hline Required effective skill (literacy) & & $\begin{array}{c}1.3460 * * * \\
(0.0443)\end{array}$ & & $\begin{array}{c}1.6864 * * * \\
(0.0626)\end{array}$ & & $\begin{array}{c}1.7700 * * * \\
(0.0754)\end{array}$ \\
\hline Overperformance effective skill (literacy) & & $\begin{array}{c}0.9765 \\
(0.0896)\end{array}$ & & $\begin{array}{c}1.9440 * * * \\
(0.1431)\end{array}$ & & $\begin{array}{c}1.9189 * * * \\
(0.1517)\end{array}$ \\
\hline Underperformance effective skill (literacy) & & $\begin{array}{c}1.0700 \\
(0.0731)\end{array}$ & & $\begin{array}{c}0.6689 * * * \\
(0.0473)\end{array}$ & & $\begin{array}{c}0.7548 * * * \\
(0.0515)\end{array}$ \\
\hline Observations & 32,368 & 32,361 & 32,242 & 32,236 & 32,304 & 32,297 \\
\hline Number of groups & 22 & 22 & 22 & 22 & 22 & 22 \\
\hline
\end{tabular}

Odd ratios and standard errors in parentheses; ${ }^{* *} p<0.01, * * p<0.05,{ }^{*} p<0.1 ;$ Controls include age, age 2 ; All figures are weighted

\begin{tabular}{|c|c|c|c|c|c|c|}
\hline Likelihood ratio test & $\begin{array}{c}\text { Int. } \\
\text { Model }\end{array}$ & $\begin{array}{c}\text { Job } \\
\text { Satisfaction }\end{array}$ & $\begin{array}{c}\text { Int. } \\
\text { Model }\end{array}$ & $\begin{array}{l}\text { Political } \\
\text { Efficacy }\end{array}$ & $\begin{array}{c}\text { Int. } \\
\text { Model }\end{array}$ & $\begin{array}{l}\text { Social } \\
\text { Trust }\end{array}$ \\
\hline log likelihood & -15504 & -15379 & -21024 & -20336 & -18089 & -17464 \\
\hline Deviance $^{1}\left(D_{i}\right)$ & 31008 & 30758 & 42048 & 40672 & 36178 & 34928 \\
\hline Decrease in deviance (DO-Di) compared to Intercept model & & 250 & & 1376 & & 1250 \\
\hline Degrees of freedom & & $d f=3$ & & $d f=3$ & & $\mathrm{df}=3$ \\
\hline Chi-squared value of decrease compared to Intercept model & & $\begin{array}{c}\mathrm{p}<0.005 \\
* * *\end{array}$ & & $\begin{array}{c}\mathrm{p}<0.005 \\
* * *\end{array}$ & & $\begin{array}{c}\mathrm{p}<0.005 \\
* * *\end{array}$ \\
\hline
\end{tabular}

${ }^{1}$ Deviance $=-2 *(\log$ likelihood), see Snijders and Bosker, 2012: $97 f f$. 
TABLE A4A-C - EXPLORING THE IMPACT OF SKILL PROFICIENCY, SKILL USE, AND EFFECTIVE SKILL - ROBUSTNESS CHECK: SEPARATE PVS

TABLE A4a: Using PVNUM2 only

\begin{tabular}{|c|c|c|c|c|c|c|c|c|c|}
\hline Model & 1 & 2 & 3 & 4 & 5 & 6 & 7 & 8 & 9 \\
\hline VARIABLES & $\begin{array}{l}\text { Int. } \\
\text { Model }\end{array}$ & $\begin{array}{c}\text { Job } \\
\text { Satisfaction }\end{array}$ & $\begin{array}{c}\text { Job } \\
\text { Satisfaction }\end{array}$ & $\begin{array}{c}\text { Int. } \\
\text { Model }\end{array}$ & $\begin{array}{l}\text { Political } \\
\text { Efficacy }\end{array}$ & $\begin{array}{l}\text { Political } \\
\text { Efficacy }\end{array}$ & $\begin{array}{l}\text { Int. } \\
\text { Model }\end{array}$ & $\begin{array}{l}\text { Social } \\
\text { Trust }\end{array}$ & $\begin{array}{l}\text { Social } \\
\text { Trust }\end{array}$ \\
\hline Skill Proficiency (PVNUM2) & & $\begin{array}{c}1.0184 \\
(0.0261)\end{array}$ & $\begin{array}{c}0.5631^{* * *} \\
(0.0859)\end{array}$ & & $\begin{array}{c}1.2836^{* * *} \\
(0.0306)\end{array}$ & $\begin{array}{c}0.9135 \\
(0.1936)\end{array}$ & & $\begin{array}{c}1.2985^{* * *} \\
(0.0377)\end{array}$ & $\begin{array}{l}0.8259 \\
(0.1407)\end{array}$ \\
\hline Skill Use (PVNUM2) & & $\begin{array}{c}1.1701^{* * *} \\
(0.0203)\end{array}$ & $\begin{array}{c}0.6364 * * * \\
(0.0939)\end{array}$ & & $\begin{array}{c}1.2815^{* * *} \\
(0.0256)\end{array}$ & $\begin{array}{c}0.9047 \\
(0.1923)\end{array}$ & & $\begin{array}{c}1.2084 * * * \\
(0.0267)\end{array}$ & $\begin{array}{l}0.7615 \\
(0.1289)\end{array}$ \\
\hline $\begin{array}{l}\text { Skill Proficiency * Skill Use } \\
\text { (= Effective skill) }\end{array}$ & & & $\begin{array}{c}1.0624^{* * *} \\
(0.0156)\end{array}$ & & & $\begin{array}{l}1.0352^{*} \\
(0.0217)\end{array}$ & & & $\begin{array}{c}1.0466 * * * \\
(0.0166)\end{array}$ \\
\hline Observations & 32,368 & 32,368 & 32,368 & 32,242 & 32,242 & 32,242 & 32,304 & 32,304 & 32,304 \\
\hline Number of groups & 22 & 22 & 22 & 22 & 22 & 22 & 22 & 22 & 22 \\
\hline
\end{tabular}

Odd ratios and standard errors in parentheses; ${ }^{* * *} p<0.01,{ }^{* *} p<0.05,{ }^{*} p<0.1$; Controls include age, age2; All figures are weighted

\begin{tabular}{|c|c|c|c|c|c|c|c|c|c|}
\hline Likelihood ratio test & $\begin{array}{l}\text { Int. } \\
\text { Model }\end{array}$ & $\begin{array}{c}\text { Job } \\
\text { Satisfaction }\end{array}$ & $\begin{array}{c}\text { Job } \\
\text { Satisfaction }\end{array}$ & $\begin{array}{l}\text { Int. } \\
\text { Model }\end{array}$ & $\begin{array}{l}\text { Political } \\
\text { Efficacy }\end{array}$ & $\begin{array}{l}\text { Political } \\
\text { Efficacy }\end{array}$ & $\begin{array}{l}\text { Int. } \\
\text { Model }\end{array}$ & $\begin{array}{l}\text { Social } \\
\text { Trust }\end{array}$ & $\begin{array}{l}\text { Social } \\
\text { Trust }\end{array}$ \\
\hline log likelihood & -15504 & -15445 & -15437 & -21024 & -20471 & -20467 & -18089 & -17715 & -17710 \\
\hline Deviance $^{1}\left(D_{i}\right)$ & 31008 & 30890 & 30874 & 42048 & 40942 & 40934 & 36178 & 35430 & 35420 \\
\hline Decrease in deviance (D0-Di) compared to Intercept model & & 118 & 134 & & 1106 & 1114 & & 748 & 758 \\
\hline Degrees of freedom & & $\mathrm{df}=2$ & $d f=3$ & & $\mathrm{df}=2$ & $d f=3$ & & $\mathrm{df}=2$ & $d f=3$ \\
\hline Chi-squared value of decrease compared to Intercept model & & $\begin{array}{c}\mathrm{p}<0.005 \\
* * *\end{array}$ & $\begin{array}{c}\mathrm{p}<0.005 \\
* * *\end{array}$ & & $\begin{array}{c}\mathrm{p}<0.005 \\
* * *\end{array}$ & $\begin{array}{c}\mathrm{p}< \\
0.005 \\
* * *\end{array}$ & & $\begin{array}{c}\mathrm{p}<0.005 \\
* * *\end{array}$ & $\begin{array}{c}\mathrm{p}<0.005 \\
* * *\end{array}$ \\
\hline Additional decrease in deviance (Nested models) & & & $\begin{array}{c}\mathrm{D}_{\mathrm{M} 2}-\mathrm{D}_{\mathrm{M} 1} \\
16\end{array}$ & & & $\begin{array}{c}D_{M 6}-D_{M 5} \\
8\end{array}$ & & & $\begin{array}{c}D_{\mathrm{M} 10}-D_{\mathrm{M} 9} \\
10\end{array}$ \\
\hline Chi-squared value of decrease (Nested models) & & & $\begin{array}{c}\mathrm{p}<0.005 \\
* * *\end{array}$ & & & $\begin{array}{c}\mathrm{p}<0.05 \\
* *\end{array}$ & & & $\begin{array}{c}\mathrm{p}<0.025 \\
* *\end{array}$ \\
\hline Degrees of freedom & & & $d f=3$ & & & $d f=3$ & & & $d f=3$ \\
\hline
\end{tabular}

${ }^{1}$ Deviance $=-2^{*}(\log$ likelihood $)$, see Snijders and Bosker, 2012: $97 f f$ 
TABLE A4b: Using PVNUM7 only

\begin{tabular}{|c|c|c|c|c|c|c|c|c|c|}
\hline Model & 1 & 2 & 3 & 4 & 5 & 6 & 7 & 8 & 9 \\
\hline VARIABLES & $\begin{array}{l}\text { Int. } \\
\text { Model }\end{array}$ & $\begin{array}{c}\text { Job } \\
\text { Satisfaction }\end{array}$ & $\begin{array}{c}\text { Job } \\
\text { Satisfaction }\end{array}$ & $\begin{array}{l}\text { Int. } \\
\text { Model }\end{array}$ & $\begin{array}{l}\text { Political } \\
\text { Efficacy }\end{array}$ & $\begin{array}{l}\text { Political } \\
\text { Efficacy }\end{array}$ & $\begin{array}{c}\text { Int. } \\
\text { Model }\end{array}$ & $\begin{array}{l}\text { Social } \\
\text { Trust }\end{array}$ & $\begin{array}{l}\text { Social } \\
\text { Trust }\end{array}$ \\
\hline Skill Proficiency (PVNUM2) & & $\begin{array}{c}1.0164 \\
(0.0255)\end{array}$ & $\begin{array}{c}0.4648 * * * \\
(0.0782)\end{array}$ & & $\begin{array}{c}1.2697^{* * *} \\
(0.0310)\end{array}$ & $\begin{array}{c}0.8981 \\
(0.1725)\end{array}$ & & $\begin{array}{c}1.3103^{* * *} \\
(0.0346)\end{array}$ & $\begin{array}{c}0.9097 \\
(0.1268)\end{array}$ \\
\hline Skill Use (PVNUM2) & & $\begin{array}{c}1.1710 * * * \\
(0.0228)\end{array}$ & $\begin{array}{c}0.5237^{* * * *} \\
(0.0866)\end{array}$ & & $\begin{array}{c}1.2859 * * * \\
(0.0265)\end{array}$ & $\begin{array}{c}0.9019 \\
(0.1729)\end{array}$ & & $\begin{array}{c}1.2044 * * * \\
(0.0241)\end{array}$ & $\begin{array}{c}0.8298 \\
(0.1152)\end{array}$ \\
\hline $\begin{array}{l}\text { Skill Proficiency * Skill Use } \\
\text { (= Effective skill) }\end{array}$ & & & $\begin{array}{c}1.0832 * * * \\
(0.0176)\end{array}$ & & & $\begin{array}{l}1.0358 * \\
(0.0196)\end{array}$ & & & $\begin{array}{c}1.0374 * * * \\
(0.0141)\end{array}$ \\
\hline Observations & 32,368 & 32,368 & 32,368 & 32,242 & 32,242 & 32,242 & 32,304 & 32,304 & 32,304 \\
\hline Number of groups & 22 & 22 & 22 & 22 & 22 & 22 & 22 & 22 & 22 \\
\hline
\end{tabular}

Odd ratios and standard errors in parentheses; ${ }^{* *} p<0.01,{ }^{* *} p<0.05,{ }^{*} p<0.1$; Controls include age, age2; All figures are weighted

\begin{tabular}{|c|c|c|c|c|c|c|c|c|c|}
\hline Likelihood ratio test & $\begin{array}{c}\text { Int. } \\
\text { Model }\end{array}$ & $\begin{array}{c}\text { Job } \\
\text { Satisfaction }\end{array}$ & $\begin{array}{c}\text { Job } \\
\text { Satisfaction }\end{array}$ & $\begin{array}{c}\text { Int. } \\
\text { Model }\end{array}$ & $\begin{array}{l}\text { Political } \\
\text { Efficacy }\end{array}$ & $\begin{array}{l}\text { Political } \\
\text { Efficacy }\end{array}$ & $\begin{array}{c}\text { Int. } \\
\text { Model }\end{array}$ & $\begin{array}{l}\text { Social } \\
\text { Trust }\end{array}$ & $\begin{array}{l}\text { Social } \\
\text { Trust }\end{array}$ \\
\hline log likelihood & -15504 & -15445 & -15431 & -21024 & -20486 & -20483 & -18089 & -17705 & -17702 \\
\hline Deviance $^{1}\left(D_{i}\right)$ & 31008 & 30890 & 30862 & 42048 & 40972 & 40966 & 36178 & 35410 & 35404 \\
\hline Decrease in deviance (D0-Di) compared to Intercept model & & 118 & 146 & & 1076 & 1082 & & 768 & 774 \\
\hline Degrees of freedom & & $\mathrm{df}=2$ & $\mathrm{df}=3$ & & $\mathrm{df}=2$ & $\mathrm{df}=3$ & & $\mathrm{df}=2$ & $d f=3$ \\
\hline Chi-squared value of decrease compared to Intercept model & & $\begin{array}{c}\mathrm{p}<0.005 \\
* * *\end{array}$ & $\begin{array}{c}\mathrm{p}<0.005 \\
* * *\end{array}$ & & $\begin{array}{c}\mathrm{p}<0.005 \\
* * *\end{array}$ & $\begin{array}{c}\mathrm{p}< \\
0.005 \\
* * *\end{array}$ & & $\begin{array}{c}\mathrm{p}<0.005 \\
* * *\end{array}$ & $\begin{array}{c}\mathrm{p}<0.005 \\
* * *\end{array}$ \\
\hline \multirow{2}{*}{ Additional decrease in deviance (Nested models) } & & & $\mathrm{D}_{\mathrm{M} 2}-\mathrm{D}_{\mathrm{M} 1}$ & & & $\mathrm{D}_{\mathrm{M} 6}-\mathrm{D}_{\mathrm{M} 5}$ & & & $\mathrm{D}_{\mathrm{M} 10}-\mathrm{D}_{\mathrm{M} 9}$ \\
\hline & & & 28 & & & 6 & & & 6 \\
\hline Chi-squared value of decrease (Nested models) & & & $\begin{array}{l}\mathrm{p}<0.005 \\
* * *\end{array}$ & & & $p<0.9$ & & & $p<0.9$ \\
\hline Degrees of freedom & & & $d f=3$ & & & $d f=3$ & & & $d f=3$ \\
\hline
\end{tabular}

${ }^{1}$ Deviance $=-2 *(\log$ likelihood), see Snijders and Bosker, 2012: 97ff. 
TABLE A4c: Using PVNUM10 only

\begin{tabular}{|c|c|c|c|c|c|c|c|c|c|}
\hline Model & 1 & 2 & 3 & 4 & 5 & 6 & 7 & 8 & 9 \\
\hline VARIABLES & Int. Model & $\begin{array}{c}\text { Job } \\
\text { Satisfaction }\end{array}$ & $\begin{array}{c}\text { Job } \\
\text { Satisfaction }\end{array}$ & Int. Model & $\begin{array}{l}\text { Political } \\
\text { Efficacy }\end{array}$ & $\begin{array}{l}\text { Political } \\
\text { Efficacy }\end{array}$ & Int. Model & Social Trust & Social Trust \\
\hline Skill Proficiency (PVNUM2) & & $\begin{array}{c}1.0081 \\
(0.0272)\end{array}$ & $\begin{array}{c}0.5422 * * * \\
(0.0731)\end{array}$ & & $\begin{array}{c}1.2733^{* * *} \\
(0.0306)\end{array}$ & $\begin{array}{c}0.9601 \\
(0.2032)\end{array}$ & & $\begin{array}{c}1.3179 * * * \\
(0.0378)\end{array}$ & $\begin{array}{c}0.8931 \\
(0.1218)\end{array}$ \\
\hline Skill Use (PVNUM2) & & $\begin{array}{c}1.1746 * * * \\
(0.0228)\end{array}$ & $\begin{array}{c}0.6222 * * * \\
(0.0825)\end{array}$ & & $\begin{array}{c}1.2846 * * * \\
(0.0255)\end{array}$ & $\begin{array}{c}0.9625 \\
(0.2023)\end{array}$ & & $\begin{array}{c}1.2019 * * * \\
(0.0253)\end{array}$ & $\begin{array}{c}0.8086 \\
(0.1065)\end{array}$ \\
\hline $\begin{array}{l}\text { Skill Proficiency * Skill Use } \\
\text { (= Effective skill) }\end{array}$ & & & $\begin{array}{c}1.0652 * * * \\
(0.0137)\end{array}$ & & & $\begin{array}{c}1.0291 \\
(0.0213)\end{array}$ & & & $\begin{array}{c}1.0399 * * * \\
(0.0135)\end{array}$ \\
\hline Observations & 32,368 & 32,368 & 32,368 & 32,242 & 32,242 & 32,242 & 32,304 & 32,304 & 32,304 \\
\hline Number of groups & 22 & 22 & 22 & 22 & 22 & 22 & 22 & 22 & 22 \\
\hline
\end{tabular}

Odd ratios and standard errors in parentheses; *** $p<0.01, * * p<0.05, * p<0.1$; Controls include age, age $;$; All figures are weighted

\begin{tabular}{|c|c|c|c|c|c|c|c|c|c|}
\hline Likelihood ratio test & Int. Model & $\begin{array}{c}\text { Job } \\
\text { Satisfaction }\end{array}$ & $\begin{array}{c}\text { Job } \\
\text { Satisfaction }\end{array}$ & Int. Model & $\begin{array}{l}\text { Political } \\
\text { Efficacy }\end{array}$ & $\begin{array}{l}\text { Political } \\
\text { Efficacy }\end{array}$ & Int. Model & Social Trust & Social Trust \\
\hline log likelihood & -15504 & -15445 & -15436 & -21024 & -20482 & -20479 & -18089 & -17698 & -17694 \\
\hline Deviance $^{1}\left(D_{i}\right)$ & 31008 & 30890 & 30872 & 42048 & 40964 & 40958 & 36178 & 35396 & 35388 \\
\hline $\begin{array}{l}\text { Decrease in deviance (DO-Di) } \\
\text { compared to Intercept model }\end{array}$ & & 118 & 136 & & 1084 & 1090 & & 782 & 790 \\
\hline Degrees of freedom & & $\mathrm{df}=2$ & $d f=3$ & & $\mathrm{df}=2$ & $d f=3$ & & $\mathrm{df}=2$ & $d f=3$ \\
\hline Chi-squared value of decrease & & $p<0.005$ & $p<0.005$ & & $p<0.005$ & $p<0.005$ & & $p<0.005$ & $p<0.005$ \\
\hline compared to Intercept model & & $* * *$ & $* * *$ & & $* * *$ & $* * *$ & & $* * *$ & $* * *$ \\
\hline Additional decrease in deviance & & & $\mathrm{D}_{\mathrm{M} 2}-\mathrm{D}_{\mathrm{M} 1}$ & & & $\mathrm{D}_{\mathrm{M6}}-\mathrm{D}_{\mathrm{M} 5}$ & & & $\mathrm{D}_{\mathrm{M} 10}-\mathrm{D}_{\mathrm{M} 9}$ \\
\hline (Nested models) & & & 18 & & & 6 & & & 8 \\
\hline $\begin{array}{l}\text { Chi-squared value of decrease } \\
\text { (Nested models) }\end{array}$ & & & $\begin{array}{c}\mathrm{p}<0.005 \\
* * *\end{array}$ & & & $p<0.9$ & & & $\mathrm{p}<0.05 * *$ \\
\hline Degrees of freedom & & & $d f=3$ & & & $d f=3$ & & & $\mathrm{df}=3$ \\
\hline
\end{tabular}

${ }^{1}$ Deviance $=-2 *(\log$ likelihood), see Snijders and Bosker, 2012: $97 f f$. 
TABLE A5 - COMPARISON OF MISMATCH INDICATORS; DV: JOB SATISFACTION

SAMPle: Entry Age MALE Fulltime EMPloyees

Odds ratios based on multilevel mixed-effects logistic regression models, standard errors in parentheses; All continuous independent variables are standardised with std(1) and mean(0)

\begin{tabular}{lc}
\hline VARIABLES & $\begin{array}{r}\text { Model 1 } \\
\text { Effective sk } \\
\text { matching } \\
\text { model (2018) }\end{array}$ \\
\hline Required effective skill (std) & $1.2596^{* * *}$ \\
Overperformance effective skill (std) & $(0.0551)$ \\
& 0.9571 \\
Underperformance effective skill (std) & $(0.0262)$ \\
& $0.9384^{*}$ \\
& $(0.0342)$
\end{tabular}

Skill use (D. = Dummy)

$\begin{array}{ccc}1.1551 * * * & 1.1572 * * * & 1.1474 * * * \\ (0.0400) & (0.0373) & (0.0394)\end{array}$

Overskilled (Allen et al) (D.)

0.8674

(0.1127)

Underskilled (Allen et al) (D.)

0.8463

(0.1190)

Overskilled (Pellizzari/Fichen) (D.)

Underskilled (P./F.) (D.)

Required Education (ORU) (std)

Overeducation (ORU) (std)

Undereducation (ORU) (std)

Overskilled according to DSA (D.)

Underskilled acc. to DSA (D.)

Mixed acc. to DSA (D.)

\begin{tabular}{lllll}
\hline$N_{\text {individuals }}$ & 11,316 & 11,316 & 11,189 & 11,248
\end{tabular}

$\mathrm{N}_{\text {countries }}$

22

22

22

22

\begin{tabular}{|c|c|c|c|c|}
\hline Likelihood ratio test & Model 1 & Model 2 & Model 3 & Model 4 \\
\hline log likelihood & -5523 & -5537 & -5477 & -5480 \\
\hline Deviance $^{1}\left(D_{i}\right)$ & 11046 & 11074 & 10954 & 10960 \\
\hline $\begin{array}{l}\text { Decrease in deviance compared to } \\
\text { Intercept model }\left(D_{0}-D_{i}\right)^{2}\end{array}$ & 60 & 32 & 32 & 80 \\
\hline Degrees of freedom & $(d f=3)$ & $(d f=3)$ & $(d f=3)$ & $(d f=4)$ \\
\hline Chi-squared value & $p<0.005^{* * *}$ & $\mathrm{p}<0.005^{* * *}$ & $p<0.005^{* * *}$ & $\mathrm{p}<0.005^{* * *}$ \\
\hline
\end{tabular}

